\title{
5-(N,N-Dimethyl)Amiloride-sensitive Na-Li Exchange in Isolated Specimens of Human Atrium
}

\author{
Helge H. Rasmussen, * Robert D. Harvey, Edward J. Cragoe, Jr., and Robert E. Ten Eick \\ The Reingold ECG Center (Division of Cardiology, ${ }^{*}$ Department of Medicine) and the ${ }^{\ddagger}$ Department of Pharmacology, Northwestern \\ University, Chicago, Illinois 60611; and ${ }^{\S}$ Merck, Sharp and Dohme Research Laboratories, West Point, Pennsylvania 19486
}

\begin{abstract}
To examine if a transmembrane $\mathrm{Na}-\mathrm{Li}$ exchange similar to that reported to occur in human blood cells can be demonstrated in the heart, we incubated specimens of human atrium in cold $\left(2-3^{\circ} \mathrm{C}\right)$ Li-Tyrode's solution. The Li-loaded, Na-depleted specimens were then transferred to warm $\left(30^{\circ} \mathrm{C}\right) \mathrm{Na}$-Tyrode's solution. After transfer the membrane potential hyperpolarized to a level more negative than the equilibrium potential for $\mathrm{K}^{+}$. The hyperpolarization was inhibited by acetylstrophanthidin or $\mathrm{K}^{+}$-free solution indicating that it was due to current produced by the $\mathrm{Na}, \mathrm{K}$-pump responding to a $\mathrm{Na}$ load. This suggested that intracellular $\mathrm{Li}^{+}$had been exchanged for $\mathrm{Na}^{+}$. The hyperpolarization was abolished by $10 \mu \mathrm{M} 5-(N, N-$ dimethyl)amiloride while $10 \mu \mathrm{M}$ bumetanide had no effect, findings that are consistent with the notion that the exchange of intracellular $\mathrm{Li}^{+}$for extracellular $\mathrm{Na}^{+}$occurs via an operational mode of the $\mathrm{Na}-\mathrm{H}$ exchanger rather than being mediated through a mechanism involving the $\mathrm{Na} / \mathrm{K} / 2 \mathrm{Cl}$ cotransporter.
\end{abstract}

\section{Introduction}

It has been suggested that the increase in red blood cell $\mathrm{Na}-\mathrm{Li}$ counter transport demonstrated in many studies to be associated with essential hypertension may reflect a pathogenetically important transport abnormality also present in cells of other tissues $(1,2)$. However, this hypothesis has been difficult to substantiate partly because a $\mathrm{Na}-\mathrm{Li}$ counter transport resembling that in blood cells is yet to be demonstrated in other human organ systems and partly because the physiological role and mechanistic basis of this counter transporter is uncertain.

A study of transmembrane $\mathrm{Li}^{+}$transport in cat papillary muscles has suggested that $\mathrm{Li}^{+}$is passively distributed in the heart (3), implying that $\mathrm{Na}-\mathrm{Li}$ counter transport does not occur in heart. However, because the rate and apparently even the presence or absence of $\mathrm{Na}-\mathrm{Li}$ counter transport is species dependent (4), it should not be assumed that $\mathrm{Li}^{+}$is also passively distributed in the human heart. We have addressed the question of whether $\mathrm{Na}-\mathrm{Li}$ counter transport can be demonstrated in human cardiac tissue.

The counter transporter can function in either $\mathrm{Na}-\mathrm{Li}$, $\mathrm{Li}-\mathrm{Li}$, or $\mathrm{Na}-\mathrm{Na}$ exchange modes (5), but none of these can be

Address reprint requests to Dr. R. E. Ten Eick, Department of Pharmacology, Northwestern University, 303 E. Chicago Avenue, Chicago, IL 60611 .

Received for publication 18 August 1986 and in revised form 26 May 1988.

J. Clin. Invest.

(c) The American Society for Clinical Investigation, Inc.

$0021-9738 / 88 / 10 / 1366 / 10 \quad \$ 2.00$

Volume 82, October 1988, 1366-1375 of functional significance because normally $\mathrm{Li}^{+}$is present in the human body only in very low concentrations (4) and $\mathrm{Na}-\mathrm{Na}$ exchange can contribute nothing to maintaining homeostasis. The counter transporter could be an evolutionary remnant that has lost its physiological role (4) or, alternatively, it could be a mechanism that normally performs a more meaningful ionic exchange function. One such mechanism, the $\mathrm{Na}-\mathrm{H}$ exchanger, can bind $\mathrm{Li}^{+}$with high affinity and has many features in common with the $\mathrm{Na}-\mathrm{Li}$ counter transport mechanism (2). It has therefore been suggested that $\mathrm{Na}-\mathrm{Li}$ counter transport may be an operational mode of the $\mathrm{Na}-\mathrm{H}$ exchanger. However, there also is evidence against this idea. An apparent lack of sensitivity of the $\mathrm{Na}-\mathrm{Li}$ counter transport in red blood cells to amiloride $(6,7)$ suggests that the counter transport may not be mediated by the $\mathrm{Na}-\mathrm{H}$ exchange mechanism, and inhibition by furosemide $(5,6)$ suggests an alternative hypothesis that $\mathrm{Na}-\mathrm{Li}$ counter transport can be mediated by a $\mathrm{Na} / \mathrm{K} / 2 \mathrm{Cl}$ cotransporter, a mechanism in which $\mathrm{Li}^{+}$can substitute for $\mathrm{Na}^{+}(8)$.

We have examined the effect of inhibition of both the $\mathrm{Na}-\mathrm{H}$ exchanger and the $\mathrm{Na} / \mathrm{K} / 2 \mathrm{Cl}$ cotransporter on the development of an intracellular $\mathrm{Na}$-load in exchange for a $\mathrm{Li}$ load in specimens of human atrial appendage. Li-loaded specimens were transferred to $\mathrm{Li}^{+}$-free $\mathrm{Na}$-Tyrode's solution to allow oppositely directed concentration gradients to develop and thus facilitate $\mathrm{Na}-\mathrm{Li}$ counter transport. This approach is similar to that used for its study in red blood cells (9). After transfer, membrane potential $\left(E_{\mathrm{m}}\right)^{1}$ transiently hyperpolarized to levels more negative than the equilibrium potential for $\mathrm{K}^{+}$ $\left(E_{\mathrm{K}}\right)$, a phenomenon attributed to electrogenic pumping by the $\mathrm{Na}, \mathrm{K}$-pump of an intracellular $\mathrm{Na}$ load exchanged for the $\mathrm{Li}$ load. The hyperpolarization was abolished by $5-(N, N$-dimethyl)amiloride, while bumetanide had no effect. These findings suggest that $\mathrm{Na}-\mathrm{Li}$ exchange can occur in human cardiac tissue and that the exchange appears to be mediated by the $\mathrm{Na}-\mathrm{H}$ exchanger rather than by the $\mathrm{Na} / \mathrm{K} / 2 \mathrm{Cl}$ cotransporter.

\section{Methods}

Specimens of atrial appendage, routinely excised to facilitate cannulation of the right atrium, were obtained from patients undergoing coronary artery bypass surgery. None of the patients had untreated hypertension and specimens from patients who had received cardiac glycosides preoperatively were excluded. The age of the patients was $64 \pm 9 \mathrm{yr}$ (mean \pm SD). All institutional and U. S. Department of Health and Human Services guidelines for human subject research were followed. A second series of experiments using guinea pig atria (obtained as described in reference 10 ) was also performed.

Immediately after excision, unless otherwise indicated, specimens were placed in cold $\left(2-3^{\circ} \mathrm{C}\right) \mathrm{Li}$-Tyrode's solution containing (in $\mathrm{mM}$ ):

1. Abbreviations used in this paper: $\mathrm{ACh}$, acetylcholine; $E_{\mathrm{K}}$, equilibrium potential for $\mathrm{K}^{+} ; E_{\mathrm{M}}$, membrane potential; TTX, tetrodotoxin. 
$\mathrm{LiCl} 150, \mathrm{KCl} 1, \mathrm{MgCl}_{2} 1.1, \mathrm{CaCl}_{2} 1.8$, dextrose 11 , Hepes buffer 5 , and $\mathrm{NaOH} 2.25\left(\mathrm{pH} 7.5\right.$ at $30^{\circ} \mathrm{C}$ and 7.7 at $2^{\circ} \mathrm{C}$ ). 70 min after excision, trabeculae dissected from the specimens were transferred to cold solutions of similar composition except for containing, unless otherwise indicated, $0.5 \mathrm{mM} \mathrm{BaCl}_{2}$ (to increase membrane resistance by reducing $\mathrm{K}$ channel conductance, see reference 11 ), and $20 \mathrm{mM} \mathrm{KCl}$. Changes in the $\mathrm{K}^{+}$concentration were made by isosmolar substitution of $\mathrm{KCl}$ for $\mathrm{LiCl}$. After an additional $20 \mathrm{~min}$ trabeculae were transferred to a $1.2-\mathrm{ml}$ tissue chamber perfused $(3-4 \mathrm{ml} / \mathrm{min})$ with warm $\left(30 \pm 0.2^{\circ} \mathrm{C}\right)$ Tyrode's solution containing $131 \mathrm{mM} \mathrm{Na}^{+}$and $0.5 \mathrm{mM} \mathrm{Ba}^{2+}$, unless otherwise indicated. All warm solutions contained $\mathrm{BaCl}_{2}$ and $\mathrm{KCl}$ in concentrations identical to those of the solution used during the last 20 min of the period of cooling. The compositions of the various solutions used are summarized in Table I. Either acetylstrophanthidin $(0.5 \mu \mathrm{M})$ dissolved in ethanol $(0.1 \mathrm{mg} / \mathrm{ml})$, ouabain $(0.1 \mathrm{mM}), 5-(N, N$-dimethyl)amiloride $(10 \mu \mathrm{M})$ or tetrodotoxin (TTX, $10 \mu \mathrm{M}$ ) dissolved in water, or bumetanide $(10 \mu \mathrm{M})$ from a $1.0 \mathrm{mM}$ dimethylsulfoxide stock solution were added to the Na-Tyrode's solution in some experiments. All solutions were bubbled with $100 \% \mathrm{O}_{2}$.

The tissue while exposed to Li-Tyrode's solution was cooled to enable comparison of the time course of $E_{\mathrm{m}}$ subsequent to warming with the time course recorded subsequent to warming specimens loaded with $\mathrm{Na}^{+}$by similar cooling in $\mathrm{Na}^{+}$-containing solutions. In addition, cooling was expected to minimize any toxic effects of incubation in Li-Tyrode's solution on cellular processes. Rewarming was required for activation of the $\mathrm{Na}, \mathrm{K}$-pump. $E_{\mathrm{m}}$ was recorded as soon as possible after the onset of rewarming using a recording system described previously (12). Glass microelectrodes filled with $3 \mathrm{M} \mathrm{KCl}$, with resistances of $15-40 \mathrm{M} \Omega$, and tip potentials of $5 \mathrm{mV}$ or less were used. Impalements were regarded as reliable if the potential registered by the electrode changed virtually instantaneously when the electrode entered or was withdrawn from the cell. Independence of the recorded potential from minor vertical movements of the microelectrode was used as additional evidence for the reliability of impalements. Satisfactory impalements were usually achieved within $2 \mathrm{~min}$ after transfer of the tissue to warm Na-containing solutions. If a reliable impalement was not achieved within $4 \mathrm{~min}$, the results are not reported. Any voltage offset recorded upon withdrawal of the electrode had to be $< \pm 4 \mathrm{mV}$ and was accounted for when reporting $E_{\mathrm{m}}$. Impalements

Table I. Composition of Solutions*

\begin{tabular}{lrrrrc}
\hline Solution & $\mathrm{Li}^{+}$ & $\mathrm{Na}^{+}$ & $\mathrm{TEA}^{+}$ & $\mathrm{K}^{+}$ & $\mathrm{Ba}^{2+}$ \\
\hline 1 & 0 & 150 & 0 & 1 & 0 \\
2 & 0 & 131 & 0 & 20 & .5 \\
3 & 0 & 151 & 0 & 0 & .5 \\
4 & 148 & 2.25 & 0 & 1 & 0 \\
5 & 129 & 2.25 & 0 & 20 & .5 \\
6 & 0 & 2.25 & 150 & 1 & 0 \\
7 & 0 & 2.25 & 129 & 20 & .5 \\
8 & 149 & 2.25 & 0 & 0 & .5 \\
9 & 0 & 20 & 130 & 1 & 0 \\
10 & 0 & 20 & 111 & 20 & .5 \\
11 & 0 & 25 & 106 & 20 & .5 \\
12 & 25 & 106 & 0 & 20 & .5 \\
13 & 25 & 25 & 81 & 20 & .5 \\
& & & & & \\
\hline
\end{tabular}

* Concentrations are in mM. In addition the solutions contained: $\mathrm{Ca}^{2+} 1.8, \mathrm{Mg}^{2+} 1.1$, dextrose 11 and Hepes buffer 5 . The $2.25 \mathrm{mM}$ $\mathrm{Na}^{+}$in solutions 4-8 originated from $\mathrm{NaOH}$ used to adjust the solutions' $\mathrm{pH}$. All solutions contained the same concentration of $\mathrm{Cl}^{-}$ (157 mM). were usually made at closely adjacent sites every $2-4$ min to check the reference potential and account for any minor voltage drift.

$\mathrm{The} \mathrm{Li}^{+}$content of atrial tissue was determined in a second series of experiments. Because extracellular ionic equilibration should be faster in thin-walled than in thick-walled atria, tissue from guinea pigs rather than humans was used for these experiments. After isolation from excised hearts the atria were treated according to a protocol identical to that used for human specimens except that $E_{\mathrm{m}}$ was not recorded. For determination of $\mathrm{Li}^{+}$content the atria were blotted between sheets of filter paper, weighed and then oven-dried at $\sim 80^{\circ} \mathrm{C}$ for $48 \mathrm{~h}$ to constant weight. The volume of tissue-water was determined by subtracting the dry weight from the wet weight. The dried atria were then dissolved in $1 \mathrm{ml}$ of concentrated nitric acid, the solution was diluted to a final volume of $25 \mathrm{ml}$, and the $\mathrm{Li}^{+}$concentration was measured using an (Varian Techtron model 1200; Varian Associates, Palo Alto, CA) atomic absorption spectrophotometer equipped with a Li-natural cathode. The $\mathrm{Li}^{+}$content was then calculated. Intracellular $\mathrm{Li}^{+}$concentrations were determined from the total $\mathrm{Li}^{+}$content of the tissue and the volume of tissue-water according to the formula given in reference 3 . The extracellular space was assumed to be $0.3 \mathrm{liter} / \mathrm{kg}$ wet tissue (10).

Results are expressed as mean \pm SE. Analysis of variance (13) was used in the statistical analysis. In total, 69 experiments on human atrial specimens and 7 experiments on guinea pig atria are reported.

\section{Results}

Time course of $E_{m}$ during extrusion of an Na load. Since electrogenic extrusion of intracellular $\mathrm{Na}^{+}$accumulated during exchange of $\mathrm{Na}^{+}$for a Li-load was used to demonstrate $\mathrm{Na}-\mathrm{Li}$ counter transport, the time course of $E_{\mathrm{m}}$ during extrusion of an $\mathrm{Na}$ load by the $\mathrm{Na}$, K-pump was characterized. To induce Na-loading, five specimens were incubated in Na-Tyrode's solutions cooled to $2-3^{\circ} \mathrm{C}$ for $90 \mathrm{~min}$ (14). The solutions contained $1 \mathrm{mM} \mathrm{K}^{+}$during the first 70 min (solution 1, Table I) and $20 \mathrm{mM} \mathrm{K}^{+}$and $0.5 \mathrm{mM} \mathrm{Ba}^{2+}$ (solution 2) during the last $20 \mathrm{~min}$ of cooling. The $20 \mathrm{mM} \mathrm{K}^{+}$solution used during the last 20 min of cooling was also used to rewarm the specimens and to obtain the reported data.

The time course of mean $E_{\mathrm{m}}$ after warming to $30^{\circ} \mathrm{C}$ is summarized in Fig. 1. $E_{\mathrm{m}}$ became increasingly negative, reaching a maximal level $\left(E_{\max }\right)$ at $14.0 \pm 2.3 \mathrm{~min}$ after the onset of warming of $-79.2 \pm 1.4 \mathrm{mV}$, before decaying towards less negative levels. Mean $E_{\max }$ was $28 \mathrm{mV}$ more negative than the level expected for $E_{\mathrm{K}}$ in human atrial tissue in $20 \mathrm{mM} \mathrm{K}^{+}$ under steady state conditions (i.e., $\sim-51 \mathrm{mV}$ ). We have demonstrated previously that such a hyperpolarization of $E_{\mathrm{m}}$ upon

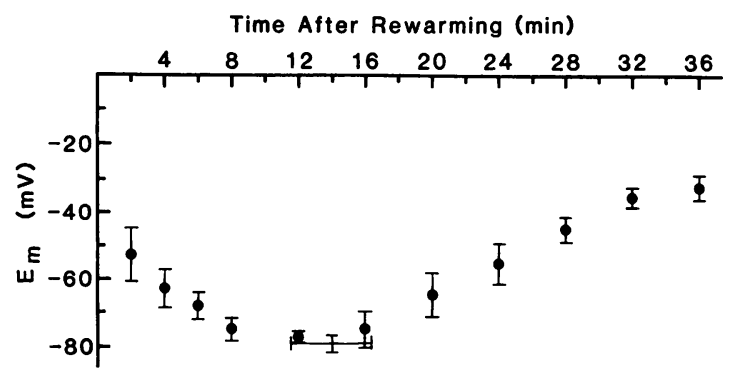

Figure 1. Hyperpolarization of Na-loaded specimens. The time course of mean $E_{\mathrm{m}}( \pm \mathrm{SE})$ recorded during rewarming is plotted for five specimens cooled for $90 \mathrm{~min}$ in Na-Tyrode's solutions. Mean $E_{\max }$ and the mean duration from the onset of rewarming until $E_{\max }$ was reached is indicated by the crossed error bars. 
rewarming of cooled human atrial specimens results from electrogenic extrusion of an intracellular $\mathrm{Na}$ load by the $\mathrm{Na}$, K-pump (12).

Time course of $E_{m}$ of Li-loaded specimens. Nine specimens incubated for $90 \mathrm{~min}$ in cold Li-Tyrode's solutions (solutions 4 and 5) to induce an intracellular Li-load were transferred to warm $\mathrm{Na}$-Tyrode's solution containing $20 \mathrm{mM} \mathrm{K}^{+}$(solution 2 ). The time course of mean $E_{\mathrm{m}}$ after the transfer is depicted in Fig. $2 A$. Initially, during the first minute or two after rewarming, $E_{\mathrm{m}}$ rapidly fell to $\sim-40 \mathrm{mV}$ and then, over the next 8-10 min, $E_{\mathrm{m}}$ transiently hyperpolarized reaching a maximal level of $-59.4 \pm 0.6 \mathrm{mV}$ after $11.3 \pm 0.9 \mathrm{~min}$ before again decaying towards more positive levels. The mean $E_{\max }$ was more negative $(P<0.01)$ than the $E_{\mathrm{K}}$ expected under steady state conditions in $20 \mathrm{mM} \mathrm{K}^{+}(\sim-51 \mathrm{mV})$. Since the intracellular $\mathrm{K}^{+}$ concentration of cardiac tissue has been shown to decrease during exposure to Li-substituted solutions (3), the difference between $E_{\max }$ and the actual $E_{\mathrm{K}}$ at the time $E_{\max }$ was obtained is probably even greater than that calculated from the presumed steady state value for $E_{\mathrm{K}}$. Therefore it appears that $E_{\mathrm{m}}$ of specimens incubated in Li-Tyrode's solution also can transiently hyperpolarize to levels that are negative to $E_{\mathrm{K}}$ after they are transferred to Na-Tyrode's solution.

In some experiments, when $E_{\mathrm{m}}$ was near $E_{\max }$, small boluses $(60 \mu \mathrm{l})$ of Tyrode's solution containing $200 \mathrm{mM}$ acetylcholine (ACh) were added to the tissue bath at the inflow orifice to substantiate that $E_{\mathrm{m}}$ actually hyperpolarized to levels negative to $E_{\mathrm{K}}$. The effect of $\mathrm{ACh}$ in one such experiment is shown in Fig. 2 B. A small transient depolarization was recorded following the administration of ACh-containing solution. Because ACh increases atrial membrane $\mathrm{K}$ conductance (14), it is expected to enhance inward, depolarizing $\mathrm{K}$ current at potentials negative to $E_{\mathrm{K}}$ and enhance outward, hyperpo-
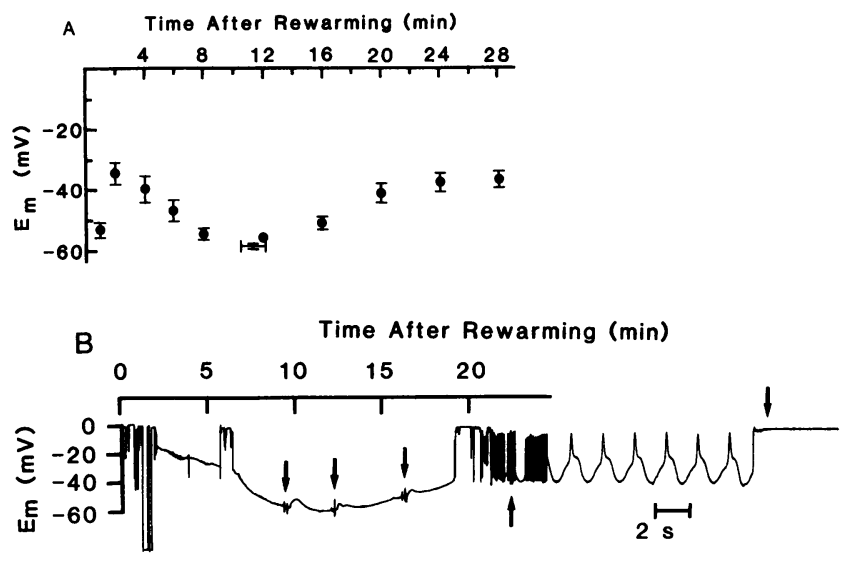

Figure 2. (A) Hyperpolarization of Li-loaded specimens. The time course of mean $E_{\mathrm{m}}$ recorded after transferring nine specimens from cold Li-Tyrode's solution to warm Na-Tyrode's solution is plotted. $(B)$ Typical time course of $E_{\mathrm{m}}$ of Li-loaded specimen. $E_{\mathrm{m}}$ was recorded after transferring the specimen from cold Li-Tyrode's solution to warm Na-Tyrode's solution. Transient depolarizations were induced when $60 \mu \mathrm{l}$ boluses of solution containing $\mathrm{ACh}$ were added at the inflow orifice of the tissue bath 9,12 , and 16 min after the transfer (administered at the times indicated by arrows). The electrode was placed extracellularly at $\sim 19$ min to verify the zero $\mathrm{mV}$ level. Reimpalement was achieved at $22 \mathrm{~min}$ and the specimen was found to be spontaneously active. After reimpalement ACh caused a small hyperpolarization and a brief arrest of spontaneous activity. larizing $\mathrm{K}$ current at potentials positive to $E_{\mathrm{K}}(15)$. The depolarization induced by $\mathrm{ACh}$ (Fig. $2 B$ ) therefore confirms that $E_{\mathrm{m}}$ was negative to $E_{\mathrm{K}}$. The response to $\mathrm{ACh}$ also indicates that under these experimental conditions, $0.5 \mathrm{mM} \mathrm{Ba}^{2+}$ does not completely block ACh-sensitive $\mathrm{K}$ channels in human atrial tissue, a result consistent with findings that a concentration of $1 \mathrm{mM} \mathrm{Ba}^{2+}$ is required to block $\mathrm{ACh}$-induced $\mathrm{K}$ currents in Purkinje strands completely (15). Even higher concentrations of $\mathrm{Ba}^{2+}$ might be required for atrial tissue that presumably has a greater density of $\mathrm{ACh}$ receptors than ventricular tissue.

Requirement of the hyperpolarization for $\mathrm{Li}$ - or Na-loading. Experiments were performed to examine the requirement for intracellular $\mathrm{Li}^{+}$or $\mathrm{Na}^{+}$in the mechanism generating the hyperpolarization depicted in Figs. 1 and 2. Six specimens were incubated for $90 \mathrm{~min}$ in cold tetraethylammonium chloride (TEA-Cl)-substituted Tyrode's solution (solutions 6 and 7) and then transferred to warm $\mathrm{Na}$-Tyrode's solution containing $20 \mathrm{mM} \mathrm{K}^{+}$(solution 2).

The time course of mean $E_{\mathrm{m}}$ recorded after the transfer is depicted in Fig. 3. After impalement $E_{\mathrm{m}}$ initially rapidly depolarized. A similar brief early depolarization occurred when Li-loaded specimens were transferred to $\mathrm{Na}$-Tyrode's solution. After the brief early depolarization, whereas Li-loaded specimens subsequently hyperpolarized transiently to levels more negative than $E_{\mathrm{K}}$ (see Fig. $2 A$ ), no such hyperpolarization occurred after transferring specimens cooled in TEA-Tyrode's solution. Thus, intracellular loading with either $\mathrm{Li}^{+}$or $\mathrm{Na}^{+}$was required for the development of the hyperpolarization depicted in Figs. 1 and 2.

Effect of reducing the Na and $\mathrm{K}$ channel conductances. Hyperpolarization of $E_{\mathrm{m}}$ to levels more negative then $E_{\mathrm{K}}$ is usually attributed to enhanced electrogenic $\mathrm{Na}, \mathrm{K}$-pump activity $(16,17)$. However, to explain the hyperpolarization depicted in Figs. 2, $A$ and $B$, additional putative mechanisms must be considered. An outward transmembrane concentration gradient for $\mathrm{Li}^{+}$should develop after the transfer of the Li-loaded specimens to $\mathrm{Li}^{+}$-free $\mathrm{Na}$-Tyrode's solution, and since the $\mathrm{Na}$ channels in sarcolemmal membranes are permeable to $\mathrm{Li}^{+}(3,18)$, the hyperpolarization could be due to an outward diffusion of $\mathrm{Li}^{+}$via $\mathrm{Na}$ channels. In principle, the hyperpolarization might also arise from an outward diffusion of $\mathrm{Li}^{+}$through any $\mathrm{K}$ channels not blocked by $0.5 \mathrm{mM} \mathrm{Ba}{ }^{2+}$. Experiments were performed to examine these possibilities.

Specimens incubated for $90 \mathrm{~min}$ in cold Li-Tyrode's solu-

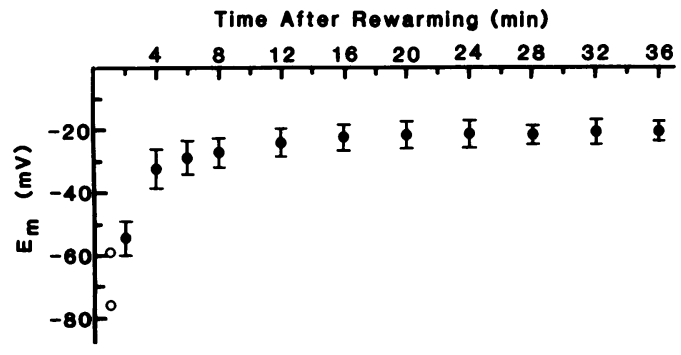

Figure 3. Time course of mean $E_{\mathrm{m}}$ upon transfer of 6 specimens incubated in cold TEA-Tyrode's solution to warm Na-Tyrode's solution. Note that, as for Li-loaded specimens (Fig. $2 A$ ), $E_{\mathrm{m}}$ rapidly depolarized after the initial impalement. However, in contrast to the Li-loaded specimens, no subsequent hyperpolarization developed. 


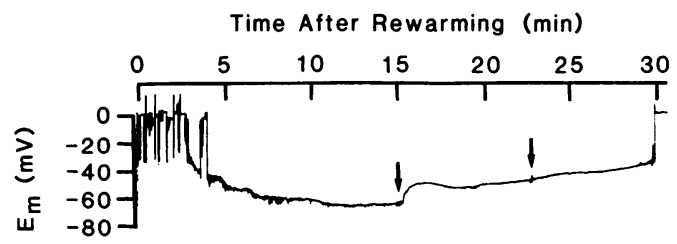

Figure 4. Effect of TTX on time course of $E_{\mathrm{m}} \cdot E_{\mathrm{m}}$ was recorded after transferring a specimen from cold Li-Tyrode's solution to warm NaTyrode's solution containing TTX. ACh (administered at the time indicated by arrows) caused a transient depolarization when $E_{\mathrm{m}}$ was near $E_{\max }$ but had no effect subsequently when $E_{\mathrm{m}}$ had depolarized to $\sim-46 \mathrm{mV}$ suggesting that $E_{\mathrm{K}}$ at that time was $\sim-46 \mathrm{mV}$.

tions (solutions 4 and 5) were transferred to warm Na-Tyrode's solution containing $20 \mathrm{mM} \mathrm{K}^{+}, 0.5 \mathrm{mM} \mathrm{Ba}^{2+}$ (solution 2) and, to decrease $\mathrm{Na}$ channel conductance (19), $10 \mu \mathrm{M}$ TTX. An example of the time course of $E_{\mathrm{m}}$ recorded after the transfer is depicted in Fig. 4. A transient hyperpolarization to $-65 \mathrm{mV}$ developed, and a bolus of solution containing ACh caused a brief depolarization when $E_{\mathrm{m}}$ was near $E_{\max }$, indicating that $E_{\mathrm{m}}$ could hyperpolarize to levels negative to $E_{\mathrm{K}}$ despite exposure to TTX. Mean $E_{\max }$ in three experiments $(-68.3 \pm 2.1$ $\mathrm{mV}$ ) was more negative than mean $E_{\max }$ in analogous experiments performed without TTX in Na-Tyrode's solution $(-59.4 \pm 0.6 \mathrm{mV}$, Fig. $2 \mathrm{~A})$ while the time from the transfer until $E_{\max }$ was reached was similar ( $12.7 \pm 1.6 \mathrm{~min}$ vs. $11.3 \pm 0.9$ $\mathrm{min})$. Since the amplitude of the hyperpolarization was increased rather than decreased by TTX, it is unlikely that an outward Li current flowing through $\mathrm{Na}$ channels underlies the hyperpolarization.

Experiments were also performed to examine the effect of $\mathrm{K}$ channel conductance on the transient hyperpolarization. Four specimens incubated for $90 \mathrm{~min}$ in cold Li-Tyrode's solutions were transferred to warm Na-Tyrode's solution containing $20 \mathrm{mM} \mathrm{K}^{+}$. In contrast to the experiments described above, none of the solutions contained $\mathrm{BaCl}_{2}$. Mean $E_{\max }$, reached $12.0 \pm 2.0 \mathrm{~min}$ after transfer, was less negative than mean $E_{\max }$ in analogous experiments performed with $\mathrm{Ba}^{2+}$ in the solutions $(-51.5 \pm 2.1 \mathrm{mV}$ vs. $-59.4 \pm 0.6 \mathrm{mV}$, Fig. $2 A)$. This indicates that an outward $\mathrm{Li}$ current through $\mathrm{Ba}^{2+}$-sensitive $\mathrm{K}$ channels cannot account for the transient hyperpolarization. Conversely, the fact that an increased membrane resistance induced by either $\mathrm{Ba}^{2+}$ or TTX caused an increase in the amplitude of the hyperpolarization, is consistant with the notion that the hyperpolarization was due to a mechanism involving electrogenic exchange or active transport.

Effect of Na, K-pump inhibition. The effect of $\mathrm{Na}, \mathrm{K}$-pump inhibition on $E_{\mathrm{m}}$ was examined to determine if the hyperpolarization were due to enhanced electrogenic $\mathrm{Na}$, K-pump activity. The Na, K-pump was inhibited by exposure of specimens to acetylstrophanthidin or $\mathrm{K}^{+}$-free, $\mathrm{Na}$-Tyrode's solution. Six specimens incubated in cold Li-Tyrode's solutions (solution 4 and then 5) were transferred to warm $\mathrm{Na}$-Tyrode's solution (solution 2) containing $20 \mathrm{mM} \mathrm{K}^{+}$and $0.5 \mu \mathrm{M}$ acetylstrophanthidin. The time course of mean $E_{\mathrm{m}}$ recorded after the transfer is depicted in Fig. 5. During the first minute $E_{\mathrm{m}}$ was similar to that observed in analogous experiments for which acetylstrophanthidin had not been included in the Na-Tyrode's solution (see Fig. $2 A$ ). However, within $2 \min E_{\mathrm{m}}$ depolarized to about $-40 \mathrm{mV}$ and remained at that level throughout the next $26 \mathrm{~min}$, a finding consistent with a fast

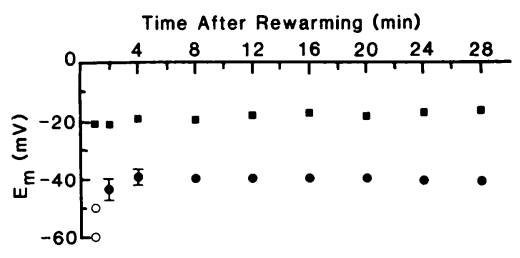

Figure 5. Effect of $\mathrm{Na}$, $\mathrm{K}$-pump inhibition on time course of mean $E_{\mathrm{m}} . E_{\mathrm{m}}$ was recorded after transferring specimens from cold Li-Tyrode's solution to warm $\mathrm{Na}$-Tyrode's solution

containing $20 \mathrm{mM} \mathrm{K}^{+}$and $0.5 \mu \mathrm{M}$ acetylstrophanthidin (circles, $n=$ 6 ) or to $\mathrm{K}^{+}$-free solution (squares, $n=6$ ). Error bars are not shown when contained within the symbols. Note that $\mathrm{Na}, \mathrm{K}$-pump inhibition abolishes the hyperpolarization recorded in analogous experiments performed without pump inhibition (Fig. 2).

onset of the inhibition of $\mathrm{Na}$, K-pump-induced hyperpolarization by acetylstrophanthidin.

In another series of experiments six cooled Li-loaded specimens were transferred to warm $\mathrm{K}^{+}$-free, $\mathrm{Na}$-Tyrode's solution (solution 3). To wash $\mathrm{K}^{+}$out of the interstitial space, the tissue was placed in cool $\mathrm{K}^{+}$-free, Li-Tyrode's solution (solution 8) during the last $20 \mathrm{~min}$ before transferring to warm Na-containing solution. The time course of mean $E_{\mathrm{m}}$ is depicted in Fig. 5. $E_{\mathrm{m}}$ was at an unchanging level from the time of the first impalements and was less negative than the $E_{\mathrm{m}}$ of those specimens exposed to acetylstrophanthidin $(0.5 \mu \mathrm{M})$ in solution 2 containing $20 \mathrm{mM} \mathrm{K}^{+}$. Abolition of the hyperpolarization by inhibiting the Na, K-pump (Fig. 5) indicates that electrogenic $\mathrm{Na}^{+}$pumping underlies the ability of Li-loaded specimens to transiently hyperpolarize after transfer to warm Na-Tyrode's solution. The results depicted in Fig. 5 also suggest that, if $\mathrm{Na}-\mathrm{Li}$ counter transport occurs after the transfer, the counter transport must be electroneutral.

Effect of $\mathrm{Li}^{+}$on Na, K-pump activity. The hyperpolarization of Li-loaded specimens could be due to electrogenic pumping of $\mathrm{Li}^{+}$by the $\mathrm{K}^{+}$-dependent, acetylstrophanthidinsensitive, Na K-pump if $\mathrm{Li}^{+}$can substitute for $\mathrm{Na}^{+}$at ligandbinding pump sites located on the cytosolic side of the sarcolemma. Alternatively, if $\mathrm{Na}-\mathrm{Li}$ counter transport occurs, electrogenic pumping of $\mathrm{Na}^{+}$which is exchanged for $\mathrm{Li}^{+}$after the transfer to Na-Tyrode's solution could underlie the hyperpolarization. Extracellular $\mathrm{Li}^{+}$competes with $\mathrm{Na}^{+}$during cellular uptake of $\mathrm{Na}^{+}$via Na-Li counter transport in red blood cells (20). This implies that if the hyperpolarizing mechanism involves counter transport, addition of $\mathrm{Li}^{+}$to the Na-containing solution should reduce uptake of $\mathrm{Na}^{+}$via $\mathrm{Na}$-Li counter transport, and hence the hyperpolarization caused by electrogenic pumping of $\mathrm{Na}^{+}$exchanged for $\mathrm{Li}^{+}$should decrease. Since the inhibitory effect of $\mathrm{Li}^{+}$on $\mathrm{Na}^{+}$uptake via the counter transport system is competitive, the inhibition should be accentuated by reducing the concentration of $\mathrm{Na}^{+}$in the Tyrode's solution. Therefore, the effect on $E_{\mathrm{m}}$ of adding $\mathrm{Li}^{+}$to solutions containing "normal" or "low" concentrations of $\mathrm{Na}^{+}$was examined.

Control experiments in which Li-loaded specimens were transferred to solutions with a reduced concentration of $\mathrm{Na}^{+}$ and no $\mathrm{Li}^{+}$were performed first. For these controls, six specimens were incubated in cold Li-Tyrode's solutions (solutions 4 and 5) for $90 \mathrm{~min}$ and then transferred to a warm solution containing $25 \mathrm{mM} \mathrm{Na}^{+}, 20 \mathrm{mM} \mathrm{K}^{+}$and, to render it isosmolar with the other solutions, $106 \mathrm{mM}$ TEA-Cl (i.e., "low" NaTyrode's solution, solution 11). The time course of mean $E_{\mathrm{m}}$ recorded after the transfer is summarized in Fig. 6, $A$. Mean 

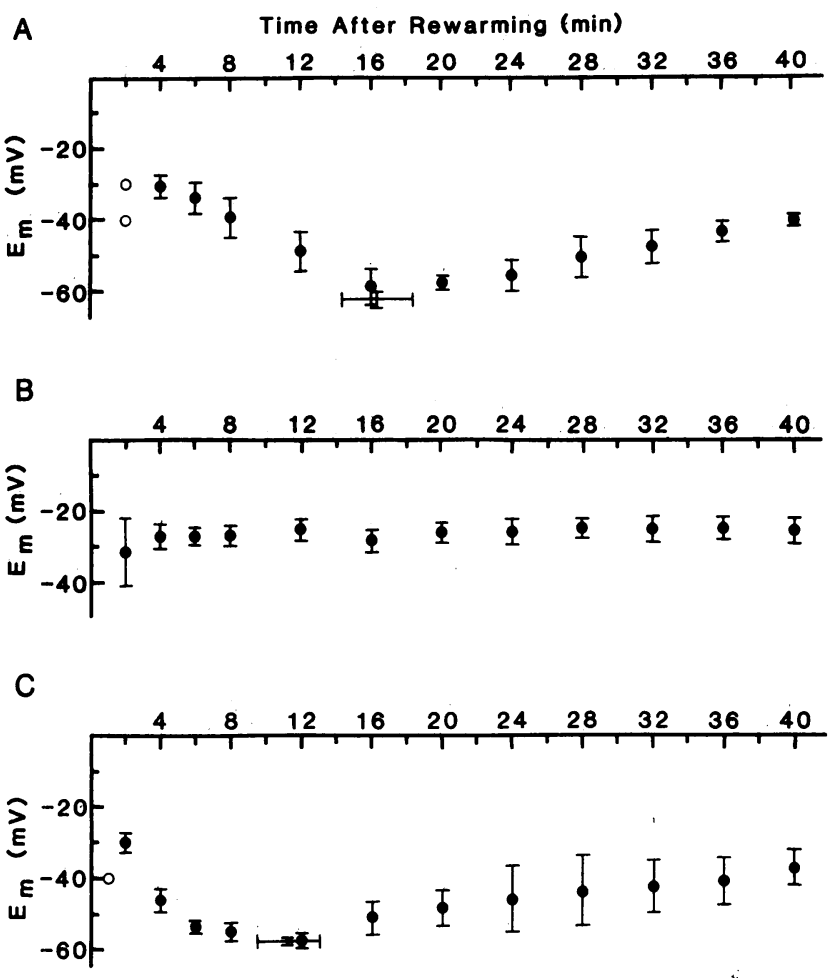

Figure 6. Effects of extracellular $\mathrm{Li}^{+}$on the time course of mean $E_{\mathrm{m}}$ at "low" and "normal" concentrations of $\mathrm{Na}$. $(A) E_{\mathrm{m}}$ recorded after transferring six specimens from cold Li-Tyrode's solution to warm low Na-Tyrode's solution. (B) $E_{\mathrm{m}}$ recorded after transferring six specimens from cold Li-Tyrode's solution to warm low $\mathrm{Li}^{+}$, low $\mathrm{Na}-\mathrm{Ty}-$ rode's solution. The transient hyperpolarization recorded in the control experiments $(A)$ was abolished by extracellular $\mathrm{Li}^{+}$. (C) $E_{\mathrm{m}}$ recorded after transferring five specimens from cold $\mathrm{Li}$-Tyrode's solution to warm low $\mathrm{Li}$ - normal $\mathrm{Na}$-Tyrode's solution. The inhibitory effect of extracellular $\mathrm{Li}^{+}$on the transient hyperpolarization $(B)$ was overcome by the increase in the $\mathrm{Na}^{+}$concentration.

$E_{\max }(-62.2 \pm 1.7 \mathrm{mV})$ was similar to mean $E_{\max }$ of Li-loaded specimens transferred to solution containing $131 \mathrm{mM} \mathrm{Na}{ }^{+}$ ( $-59.4 \pm 0.6 \mathrm{mV}$, Fig. $2 A$ ). However, the hyperpolarization developed more slowly in the $25 \mathrm{mM} \mathrm{Na}^{+}$solution (time from transfer until $E_{\max }$ was recorded was $16.3 \pm 2.1 \mathrm{~min}$ in the $25-\mathrm{mM}$ solution and $11.3 \pm 0.9 \mathrm{~min}$ in the $131-\mathrm{mM}$ solution, $P$ $<0.05$ ). As in other cases (see Figs. $2 B$ and 4) ACh administered when $E_{\mathrm{m}}$ was near $E_{\max }$, induced a very brief depolarization indicating that $E_{\mathrm{m}}$ was more negative than $E_{\mathrm{K}}$ (data not shown).

After incubation in Li-Tyrode's solutions (solutions 4 and 5) the effect on the time course of $E_{\mathrm{m}}$ of $25 \mathrm{mM} \mathrm{Li}^{+}$in a warm solution closely resembling that used for the series of control experiments described above (solution 11) was examined. The solution contained $25 \mathrm{mM} \mathrm{Na}^{+}, 20 \mathrm{mM} \mathrm{K}^{+}, 81 \mathrm{mM}$ TEA-Cl, and $25 \mathrm{mM} \mathrm{Li}^{+}$(i.e., low $\mathrm{Li}^{+}$-, low Na-Tyrode's solution, solution 13). The time course of mean $E_{m}$ recorded after the transfer of six specimens is depicted in Fig. $6 \mathrm{~B}$. No transient hyperpolarization was observed. $E_{\mathrm{m}}$ remained stable at $\sim-30$ $\mathrm{mV}$ throughout the period of recording in contrast to the hyperpolarization observed in similar solutions not containing $\mathrm{Li}^{+}$(see Fig. $6 \mathrm{~A}$ ). This suggests that extracellular $\mathrm{Li}^{+}$inhibited the exchange of an intracellular ion for extracellular $\mathrm{Na}^{+}$.

If the absence of a transient hyperpolarization (Fig. $6 \mathrm{~B}$ ) were due to competitive inhibition of cellular $\mathrm{Na}^{+}$-uptake by $\mathrm{Li}^{+}$, it should be possible to overcome the inhibition by increasing the $\mathrm{Na}^{+}$concentration in the rewarming solution containing $25 \mathrm{mM} \mathrm{Li}^{+}$. This was examined by transferring five cooled Li-loaded specimens to warm solution containing 106 (rather than 25) $\mathrm{mM} \mathrm{Na}^{+}, 20 \mathrm{mM} \mathrm{K}^{+}$and $25 \mathrm{mM} \mathrm{Li}^{+}$(solution 12). The time course of mean $E_{\mathrm{m}}$ is summarized in Fig. 6 $C$. A mean $E_{\max }$ of $-57.6 \pm 1.1 \mathrm{mV}$ was recorded $11.2 \pm 1.8 \mathrm{~min}$ after the transfer, and $\mathrm{ACh}$, administered when $E_{\mathrm{m}}$ was near $E_{\max }$, induced a depolarization (data not shown), again indicating that $E_{\mathrm{m}}$ had been negative to $E_{\mathrm{K}}$. Thus the inhibitory effect of $25 \mathrm{mM} \mathrm{Li}^{+}$on the transient pump-induced hyperpolarization (Fig. $6 \mathrm{~B}$ ) was overcome by increasing the $\mathrm{Na}^{+}$concentration from 25 to $106 \mathrm{mM}$. This indicates the involvement of extracellular $\mathrm{Na}^{+}$in the process underlying the transient hyperpolarization and supports the conclusion that an intracellular ion-load had been replaced by a Na-load. In addition, these findings also indicate that the inhibition by $\mathrm{Li}^{+}$of the hyperpolarization observed in the solution containing $25 \mathrm{mM}$ $\mathrm{Na}^{+}$(Fig. $6 \mathrm{~B}$ ) was not due to a functionally significant direct inhibitory effect of extracellular $\mathrm{Li}^{+}$on the electrogenic $\mathrm{Na}$, K-pump.

Effect of $\mathrm{Na}, \mathrm{K}$-pump inhibition on tissue content of $\mathrm{Li}^{+}$. The effect of Na, K-pump inhibition on the transient hyperpolarization of Li-loaded specimens (Fig. 5) transferred to NaTyrode's solution indicates that the hyperpolarization was due to electrogenic $\mathrm{Na}, \mathrm{K}$-pump activity. The results presented in Fig. 6 indicate that the hyperpolarization was not due to electrogenic pumping of $\mathrm{Li}^{+}$by the $\mathrm{Na}, \mathrm{K}$-pump. To further substantiate this conclusion we examined the effect of pump inhibition on the tissue content of $\mathrm{Li}^{+}$. In these experiments guinea pig atria were incubated for $90 \mathrm{~min}$ in cold Li-Tyrode's solution before being transferred to warm $\mathrm{Na}$-Tyrode's solution containing $20 \mathrm{mM} \mathrm{K}^{+}$(identical to solution 2 except for not containing $\mathrm{Ba}^{2+}$ ). The atria were exposed to $0.1 \mathrm{mM}$ ouabain before and after the transfer to Na-Tyrode's solution in one series of experiments. No ouabain was used in a second series.

At the end of the cooling period the atria contained 2.8-2.9 $\mu \mathrm{g} \mathrm{Li}^{+} / \mathrm{mg}$ dry weight $(n=2)$. These values reflect $\mathrm{Li}^{+}$contained in the extracellular and the intracellular compartments. The $\mathrm{Li}^{+}$concentration calculated from the data was 110-118 $\mathrm{mmol} /$ liter intracellular water, values in good agreement with similar data for cat papillary muscles (3). The tissue content of $\mathrm{Li}^{+}$in the atria was also determined $15 \mathrm{~min}$ after transfer to warm Na-Tyrode's solution. $\mathrm{Li}^{+}$in tissue exposed or not exposed to ouabain was similar $(0.58 \pm 0.07, n=3$ vs. $0.65 \pm 0.06$ $\mu \mathrm{g} / \mathrm{mg}$ dry weight, $n=3$, or $27.1 \pm 5.1$ vs. $27.8 \pm 2.8 \mathrm{mmol} / \mathrm{liter}$ intracellular water) suggesting that $\mathrm{Na}, \mathrm{K}$-pump inhibition had no effect on the extrusion of intracellular $\mathrm{Li}^{+}$. This finding supports the conclusion of the previous section that the hyperpolarization of Li-loaded human atrial specimens does not result from electrogenic pumping of $\mathrm{Li}^{+}$, and is consistent with the hypothesis that $\mathrm{Li}^{+}$efflux is mediated by a mechanism involving exchange with extracellular $\mathrm{Na}^{+}$.

Effect of inhibition of $\mathrm{Na} / \mathrm{K} / 2 \mathrm{Cl}$ co-transport and $\mathrm{Na}-\mathrm{H}$ exchange. Because exchange of an intracellular Li-load for extracellular $\mathrm{Na}^{+}$might involve either an operational mode of the $\mathrm{Na} / \mathrm{K} / 2 \mathrm{Cl}$ cotransporter or of the $\mathrm{Na}-\mathrm{H}$ exchanger, we examined the effect on $E_{\mathrm{m}}$ of inhibiting each of these systems.

Six specimens, Li-loaded by incubation in cold Li-Tyrode's solutions (4 and 5), were transferred to warm Na-Tyrode's solution (2). To inhibit the $\mathrm{Na} / \mathrm{K} / 2 \mathrm{Cl}$ cotransporter solutions 
2 and 5 contained $10 \mu \mathrm{M}$ bumetanide (8). The time course of mean $E_{\mathrm{m}}$ recorded during rewarming is shown in Fig. 7. Mean $E_{\max }(-59.7 \pm 1.5 \mathrm{mV})$, reached $11.0 \pm 1.4 \mathrm{~min}$ after the onset of rewarming, was not significantly different from the mean $E_{\max }$ in analogous experiments performed without bumetanide in these solutions $(-59.4 \pm 0.6 \mathrm{mV}$, Fig. $2 A)$. This indicates that the $\mathrm{Na} / \mathrm{K} / 2 \mathrm{Cl}$ cotransporter is unlikely to be involved in the sequence of events resulting in a $\mathrm{Na}, \mathrm{K}$-pump-induced hyperpolarization after transfer of $\mathrm{Li}$-loaded specimens to $\mathrm{Na}-\mathrm{Ty}$ rode's solution.

Six specimens, cooled for $90 \mathrm{~min}$ in Li-Tyrode's solutions (4 and 5) were transferred to warm Na-Tyrode's solution (2). Solutions 2 and 5 contained $10 \mu \mathrm{M} 5-(N, N$-dimethyl)amiloride, a Na-H exchange inhibitor. The time course of mean $E_{\mathrm{m}}$ during rewarming is shown in Fig. 8. After the initial impalement $E_{\mathrm{m}}$ rapidly depolarized. In analogous experiments performed without 5-(N,N-dimethyl)-amiloride in the solutions a similar early depolarization occurred (see Fig. $2 A$ and Fig. 7, 1- and 2-min mark). However, in these latter experiments $E_{\mathrm{m}}$ subsequently hyperpolarized transiently to levels more negative than $E_{\mathrm{K}}$ (see Fig. $2 A$ and Fig. 7, 10- and 12-min mark). A comparison of the results of the two experimental paradigms indicates that the hyperpolarization can be abolished by 5-( $N, N$-dimethyl)amiloride. Control experiments on $\mathrm{Na}$ loaded rather than Li-loaded atrial tissues indicated that the drug, in the concentration used, had no substantial effect on electrogenic $\mathrm{Na}^{+}$pumping in human atrial tissue (data not shown). This finding indicates that the pump-induced hyperpolarization of the Li-loaded tissue was not abolished because the $\mathrm{Na}, \mathrm{K}$-pump had been inhibited and it suggests that the $\mathrm{Na}-\mathrm{H}$ exchanger is involved in the sequence of events that result in electrogenic pumping of an intracellular Na-load developed after transferring $\mathrm{Li}$-loaded tissue to $\mathrm{Na}^{+}$-containing Tyrode's solution.

Determinants for the time course of $E_{m}$. In Li-loaded specimens transferred to Na-Tyrode's solution, the duration of the pump-induced hyperpolarization to voltages negative to $E_{\mathrm{K}}$ was long ( $>17 \mathrm{~min}$ in a typical experiment, see Fig. $2 \mathrm{~B}$ ) in comparison with time constants of $<2$ min reported for the decay of $\mathrm{Na}, \mathrm{K}$-pump currents (21). This could be interpreted to mean that $\mathrm{Na}-\mathrm{Li}$ counter transport rather than extrusion of $\mathrm{Na}^{+}$by the pump is the rate limiting determinant for the time course of $E_{\mathrm{m}}$. However, other factors also are expected to contribute to the prolonged pump-induced hyperpolarization. If, for example, intracellular pump-sites for $\mathrm{Na}$-binding were saturated, the time required for extrusion of a large $\mathrm{Na}$ load

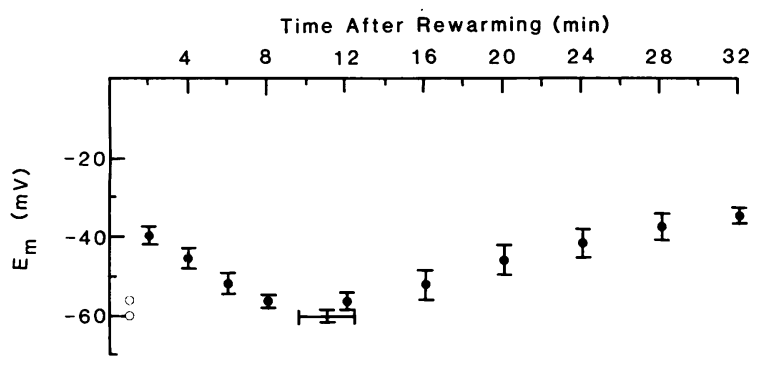

Figure 7. Effect of bumetanide ( $10 \mu \mathrm{M})$ on the time course of $E_{\mathrm{m}}$ of Li-loaded tissue. Six specimens cooled for $90 \mathrm{~min}$ in Li-Tyrode's solutions were transferred to warm Na-Tyrode's solution. The open circles indicate data from individual experiments.

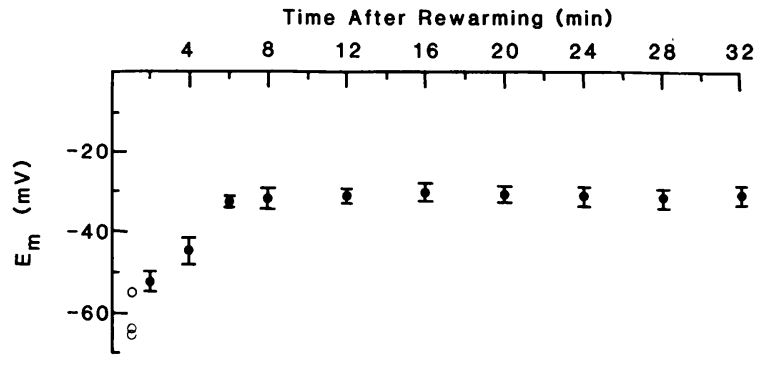

Figure 8. Effect of 5-( $N, N$-dimethyl)amiloride $(10 \mu \mathrm{M})$ on the time course of $E_{\mathrm{m}}$ of Li-loaded tissue. Six specimens cooled for $90 \mathrm{~min}$ in Li-Tyrode's solutions were transferred to warm Na-Tyrode's solution.

should be longer than that expected from the time constant for the decay of pump current for when the elevation of intracellular $\mathrm{Na}^{+}$activity is modest (12).

To evaluate the effect of the size of the Na-load on the time course of $E_{\mathrm{m}}$, a specimen was cooled for $90 \mathrm{~min}$ in solutions containing $20 \mathrm{mM} \mathrm{Na}{ }^{+}$. These solutions also contained 130 $\mathrm{mM}$ TEA-Cl and $1 \mathrm{mM} \mathrm{K}^{+}$(during the first $70 \mathrm{~min}$, solution 9) or $111 \mathrm{mM} \mathrm{TEA}-\mathrm{Cl}, 20 \mathrm{mM} \mathrm{K}^{+}$and $0.5 \mathrm{mM} \mathrm{Ba}^{2+}$ (during the subsequent $20 \mathrm{~min}$, solution 10 ). Cooling in these solutions should result in a smaller Na-load than cooling in solutions with normal $\mathrm{Na}^{+}$concentration and, because the sarcolemmal membrane has a very low permeability for $\mathrm{TEA}^{+}(18)$, less intracellular $\mathrm{K}^{+}$should be lost during cooling. Since the combination of increasing $\mathrm{K}^{+}$gradients and decaying electrogenic pump current should be the principal determinants for the time course of $E_{\mathrm{m}}$ during rewarming (see reference 12 for discussion), $E_{\mathrm{m}}$ should reach its most negative level earlier than the $E_{\mathrm{m}}$ of specimens rewarmed after cooling in normal NaTyrode's solution and, if saturation of intracellular pump-sites contributes to a prolongation of the hyperpolarization, the subsequent rate of decay should be faster.

The time course of $E_{\mathrm{m}}$ during rewarming of the cooled specimen in normal Na-Tyrode's solution containing $20 \mathrm{mM}$ $\mathrm{K}^{+}$and $0.5 \mathrm{mM} \mathrm{Ba}^{2+}$ (solution 2) is depicted in Fig. 9. $E_{\max }$ $(-81 \mathrm{mV})$ was similar to $E_{\max }$ of specimens rewarmed after cooling in normal Na-Tyrode's solutions $(-79.2 \pm 2.8 \mathrm{mV}$, Fig. $1)$, but it was reached earlier and the subsequent decay of $E_{\mathrm{m}}$ was faster (half-time for decay 3 vs. $10 \mathrm{~min}$ ).

The similarity between $E_{\max }$ after cooling with low or with normal $\mathrm{Na}^{+}$concentrations should not be taken to indicate that pump-sites were saturated at an intracellular $\mathrm{Na}^{+}$concentration of $20 \mathrm{mM}$ because the intracellular $\mathrm{Na}^{+}$concentration

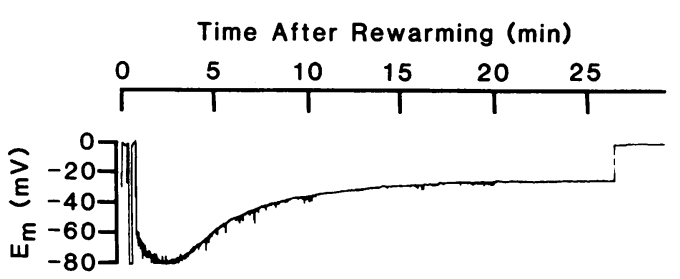

Figure 9. Effect of cooling in low Na-Tyrode's solution on time course of $E_{\mathrm{m}} . E_{\mathrm{m}}$ was recorded after transferring a specimen from cold low (20 mM) Na-Tyrode's solution to warm normal Na-Tyrode's solution. Comparison with Fig. 1 suggests that the amplitude but not the duration of the hyperpolarization is independent of the size of the $\mathrm{Na}$ load. 
after cooling may be higher than the extracellular concentration due to an inwardly directed electrical gradient during cooling. However, the longer duration of the hyperpolarization with the presumed increase in the Na-load is consistent with the notion that pump electrogenesis saturates at some experimentally, readily attainable level of intracellular $\mathrm{Na}^{+}$ activity. Quantitative estimates of this level cannot be derived from the time course of $E_{\mathrm{m}}$ because $E_{\mathrm{m}}$ is determined by a complex interaction between the effects of intracellular $\mathrm{Na}^{+}$on $\mathrm{Na}, \mathrm{K}$-pump activity and the transmembrane gradient for $\mathrm{K}^{+}$ acting in combination with the voltage dependencies of both pump current (22) and the $\mathrm{Ba}^{2+}$-induced decrease in $\mathrm{K}$ channel conductance (15). However, in principle it is not unreasonable to suggest that the prolonged hyperpolarization observed when $\mathrm{Li}$-loaded specimens were transferred to $\mathrm{Na}$-containing solutions (Fig. 2) can be explained by saturability of intracellular $\mathrm{Na}, \mathrm{K}$-pump sites rather than being indicative of a relatively slow rate of $\mathrm{Na}-\mathrm{Li}$ exchange.

\section{Discussion}

Specimens of human atrial tissue were incubated in Li-Tyrode's solution to replace partially intracellular $\mathrm{K}^{+}$and $\mathrm{Na}^{+}$ with $\mathrm{Li}^{+}$. The specimens were then transferred to Na-containing solutions to allow outward $\mathrm{Li}^{+}$and inward $\mathrm{Na}^{+}$gradients to develop. After transfer, $E_{\mathrm{m}}$ transiently hyperpolarized to levels more negative than those recorded during the subsequent steady state. The hyperpolarization could have been caused by a change in transmembrane ionic conductances or by an electrogenic mechanism involving ionic exchange or active transport.

Because Na channels are permeable to $\mathrm{Li}^{+}(18)$, it is possible that an outward flow of $\mathrm{Li}^{+}$ions through $\mathrm{Na}$ channels could have generated a hyperpolarizing current upon transfer of the specimens to $\mathrm{Li}^{+}$-free solution. However, were this the case, the amplitude of the hyperpolarization should have been reduced by TTX rather than augmented, as was found experimentally. Therefore, it is reasonable to conclude that an ion flow through $\mathrm{Na}$ channels does not account for the hyperpolarization. Li-loading may have increased $\mathrm{K}$ channel conductance (3). In principle, the increase might result in an outward flow of $\mathrm{Li}^{+}$through $\mathrm{K}$ channels and thus hyperpolarize $E_{\mathrm{m}}$. However, the depolarizing response to ACh (Figs. $2 B$ and 4) indicates that the hyperpolarization was not due to outward current through $\mathrm{ACh}$-sensitive $\mathrm{K}$ channels, and the increase in amplitude of the hyperpolarization induced by $\mathrm{Ba}^{2+}$, relative to that obtained in experiments performed without $\mathrm{Ba}^{2+}$, indicates that the hyperpolarization was not due to outward current through $\mathrm{Ba}^{2+}$-sensitive $\mathrm{K}$ channels.

An outward flow of $\mathrm{Li}^{+}$through channels insensitive to TTX, ACh and $\mathrm{Ba}^{2+}$ must, a priori, be considered a very unlikely mechanism for the hyperpolarization. Strong evidence against this possibility is provided by the experiments summarized in Fig. $6 C$. When Li-loaded specimens were transferred to $\mathrm{Li}^{+}$-containing $(25 \mathrm{mM}) \mathrm{Na}$-Tyrode's solution, $E_{\max }$ was $-57.6 \pm 1.1 \mathrm{mV}$. At the time $E_{\max }$ was recorded intracellular $\mathrm{Li}^{+}$should have been considerably less than the $\mathrm{Li}^{+}$concentration in the cooling solution $(129 \mathrm{mM})$. It follows that the equilibrium potential for $\mathrm{Li}^{+}$should be less negative than -43 $\mathrm{mV}$ (calculated from the Nernst equation), i.e., at least $14 \mathrm{mV}$ less negative than the $E_{\max }$ recorded experimentally. This indicates that the hyperpolarization cannot be accounted for by an outward flow of $\mathrm{Li}^{+}$through any species of ionic channel. Since hyperpolarization of Li-loaded specimens cannot be accounted for by change in an ionic conductance, an electrogenic mechanism should be considered. The inhibitory effect of acetylstrophanthidin (Fig. 5) indicates that electrogenic $\mathrm{Na}$, K-pump activity must be the mechanism responsible for the hyperpolarization.

Since $\mathrm{Li}^{+}$largely should have replaced intracellular $\mathrm{Na}^{+}$ and $\mathrm{K}^{+}$during incubation in $\mathrm{Li}^{+}$-substituted solutions (3), enhanced pump activity could be caused by pumping intracellular $\mathrm{Li}^{+}$or, alternatively, by pumping an intracellular $\mathrm{Na}$-load that developed after transferring the tissue to Na-containing solutions. The biological and physical properties of $\mathrm{Li}^{+}$and $\mathrm{Na}^{+}$are in several respects quite similar (23). $\mathrm{Li}^{+}$can, for example, replace $\mathrm{Na}^{+}$in the mechanism generating the upstroke of cardiac action potentials (3), and the similarity between the physicochemical properties of the two ions can interfere seriously with interpretation of ion-selective-microelectrode recordings (24). For this study, the ionic selectivity of intracellular $\mathrm{Na}$, K-pump sites is crucial for interpretation of the experimental findings. Previous studies $(3,17)$ have provided evidence against substantial outward transport of $\mathrm{Li}^{+}$by the sarcolemmal $\mathrm{Na}, \mathrm{K}$-pump. However, glycoside-induced pump inhibition was not utilized in those studies. In the present study the effect of such inhibition on the $\mathrm{Li}^{+}$-content of guinea pig atrial tissue was examined. In agreement with the previous studies $(3,17) \mathrm{Na}, \mathrm{K}$-pump activity or lack thereof had no apparent effect on $\mathrm{Li}^{+}$efflux from myocytes.

In contrast, outward transport of $\mathrm{Li}^{+}$by the $\mathrm{Na}, \mathrm{K}$-pump has been demonstrated in red blood cells, although under extreme experimental conditions $(20,25)$. However, the selectivity of $\mathrm{Na}^{+}$over $\mathrm{Li}^{+}$is so great that ouabain-sensitive $\mathrm{Li}^{+}$efflux is undetectable unless the intracellular $\mathrm{Na}^{+}$concentration is less than $1 \mathrm{mM}$ (23). Such a low concentration could not possibly be achieved during incubation in the solutions used in this study (Table I) indicating that electrogenic pumping of $\mathrm{Li}^{+}$ by the $\mathrm{Na}, \mathrm{K}$-pump is unlikely to have caused the hyperpolarization of the Li-loaded specimens. In addition, if the hyperpolarization were due to pumping of $\mathrm{Li}^{+}$, extracellular $\mathrm{Li}^{+}$would not be expected to be inhibitory at low extracellular $\mathrm{Na}^{+}$concentration (Fig. $6 \mathrm{~B}$ ) yet have no effect at normal extracellular $\mathrm{Na}^{+}$concentration (Fig: $6 C$ ). Therefore, it is reasonable to conclude that the hyperpolarization of $E_{\mathrm{m}}$ to levels more negative than $E_{\mathrm{K}}$ is not due to electrogenic pumping of intracellular $\mathrm{Li}^{+}$by the $\mathrm{Na}, \mathrm{K}$-pump. Since the $\mathrm{Na}, \mathrm{K}$-pump-induced hyperpolarization observed upon transfer of Li-loaded tissue to $\mathrm{Na}$-Tyrode's solution cannot be attributed to electrogenic pumping of $\mathrm{Li}^{+}$, it must have been due to electrogenic pumping of an intracellular $\mathrm{Na}$-load that developed after the transfer.

The cellular content of $\mathrm{Ca}^{2+}$ probably increased during incubation in the cold Li-Tyrode's solution, and, upon transfer to warm $\mathrm{Na}$-Tyrode's solution, the accumulated $\mathrm{Ca}^{2+}$ should be exchanged for $\mathrm{Na}^{+}$via the $\mathrm{Na}-\mathrm{Ca}$ exchange mechanism. This may have generated inward current (26), and the transient depolarization recorded during the first few min after the transfer (Fig. $2 A$ ) could in principle be caused by such a current. However, $\mathrm{Ca}^{2+}$ should also accumulate intracellularly during incubation of specimens in cold $\mathrm{Na}$-Tyrode's solution. A transient depolarization induced by $\mathrm{Na}-\mathrm{Ca}$ exchange current should therefore also have occurred upon transfer of these specimens to warm Na-Tyrode's solution. This was not ob- 
served (Fig. 1) suggesting that the transient depolarization of Li-loaded specimens (Fig. $2 A$ ) was not directly related to a transient $\mathrm{Ca}$-overload and an associated $\mathrm{Na}-\mathrm{Ca}$ exchange current.

A Ca load accumulated during cooling in Li-Tyrode's solution may, nevertheless, have contributed indirectly to the time course of $E_{\mathrm{m}}$ shown in Fig. $2 A$. Exchange of some intracellular $\mathrm{Ca}^{2+}$ for $\mathrm{Na}^{+}$may have provoked a small Na-load immediately after transfer and before when $E_{\mathrm{m}}$ first could be recorded. It is possible that the early depolarization of $\mathrm{Li}$ loaded specimens was due to a rapidly decaying outward $\mathrm{Na}$, K-pump current activated by the putative short-lived, early transient $\mathrm{Na}-\mathrm{load}^{2}$ occurring prior to when $\mathrm{Na}-\mathrm{Li}$ exchange causes the $\mathrm{Na}$ load of interest. Alternatively, the initial changes in $E_{\mathrm{m}}$ could indicate that exchange of $\mathrm{Li}^{+}$for $\mathrm{Na}^{+}$is electrogenic. This alternative hypothesis, however, is inconsistent with the finding that the initial, relatively negative but rapidly depolarizing $E_{\mathrm{m}}$ seen in Li-loaded specimens (Fig. $2 A$ ) was abolished when the $\mathrm{Na}, \mathrm{K}$-pump was inhibited by $\mathrm{K}^{+}$-free solutions (Fig. 5). A similar rapidly occurring initial depolarization was also observed after specimens cooled in $\mathrm{Li}^{+}$-free TEA-Tyrode's were transferred to Na-Tyrode's solution (Fig. 3), indicating that this particular depolarization was not dependent upon an intracellular Li load. It too may have involved a rapidly decaying hyperpolarizing $\mathrm{Na}$, K-pump current associated with extrusion of a $\mathrm{Na}$ load developed because of an exchange of $\mathrm{Na}^{+}$for an initial $\mathrm{Ca}$ load in a manner analogous to that discussed above for Li-loaded specimens.

While exchange of intracellular $\mathrm{Ca}^{2+}$ for extracellular $\mathrm{Na}^{+}$ may be involved indirectly in the mechanism underlying the initial, relatively negative, rapidly depolarizing $E_{\mathrm{m}}$ of $\mathrm{Li}$ loaded specimens (Fig. $2 A$ ), such an exchange cannot sponsor the subsequent hyperpolarization because the latter was found to be dependent upon an intracellular Li-load (compare Fig. 2 with Fig. 3). In addition, were $\mathrm{Na}-\mathrm{Ca}$ exchange involved, the hyperpolarization of Li-loaded specimens should not be abolished by extracellular $\mathrm{Li}^{+}$(Fig. $6 \mathrm{~B}$ ) because the $\mathrm{Na}-\mathrm{Ca}$ exchanger does not appear to have affinity for $\mathrm{Li}^{+}$(27). Therefore, the evidence is against the notion that $\mathrm{Na}-\mathrm{Ca}$ exchange underlies the hyperpolarization of $E_{\mathrm{m}}$ negative to $E_{\mathrm{K}}$.

The persistence of the hyperpolarization in the presence of $10 \mu \mathrm{M}$ bumetanide (Fig. 7) indicates that the $\mathrm{Na} / \mathrm{K} / 2 \mathrm{Cl}$ cotransporter also is not involved in the mechanism underlying the hyperpolarization. This could be taken to indicate that the mechanism for $\mathrm{Na}-\mathrm{Li}$ exchange in heart is different from that mediating $\mathrm{Na}-\mathrm{Li}$ exchange in red blood cells. Inhibition of $\mathrm{Na} / \mathrm{K} / 2 \mathrm{Cl}$ co-transport with furosemide is said to inhibit $\mathrm{Na}-\mathrm{Li}$ exchange in blood cells $(5,6)$. It should, however, be noted that millimolar concentrations of furosemide were needed to inhibit cotransport. Loop diuretics at such concentrations have been reported to exhibit nonspecific inhibitory effects on membrane transport systems other than the $\mathrm{Na} / \mathrm{K} / 2 \mathrm{Cl}$ cotransporter (8).

The $\mathrm{Na}, \mathrm{K}$-pump-induced hyperpolarization of the Liloaded specimens was abolished by $10 \mu \mathrm{M} 5-(N, N$-dimethyl)

2. Any $\mathrm{Na}$ load developed in exchange for $\mathrm{Ca}^{2+}$ in specimens cooled in Na-Tyrode's solution may not be important quantitatively because cooling can induce very large Na-loads (10). This may explain why an early transient depolarization did not develop in the experiments depicted in Fig. 1. amiloride (compare Fig. 8 with Fig. 2), suggesting that the $\mathrm{Na}-\mathrm{H}$ exchanger could be involved in the mechanism causing the hyperpolarization. In principle, if an intracellular acid-load developed as a consequence of the low extracellular $\mathrm{Na}^{+}$concentration during exposure to cold Li-Tyrode's solution, a 5-( $N, N$-dimethyl)amiloride-sensitive exchange of $\mathrm{Na}^{+}$for intracellular protons should occur after transfer to $\mathrm{Na}$-Tyrode's solution. The subsequent electrogenic Na-pumping of the $\mathrm{Na}$ load would then cause the hyperpolarization. However, development of a significant acid-load is unlikely. Cooling of the Li-Tyrode's solution should have inhibited any exchange-carrier-mediated changes in intracellular ionic composition (28). Consequently, intracellular $\mathrm{pH}$ should be determined by extracellular $\mathrm{pH}$ and $E_{\mathrm{m}} . E_{\mathrm{m}}$ in cold Li-Tyrode's solution was $\sim-15 \mathrm{mV}$ (data not shown) and extracellular $\mathrm{pH}$ was $\sim 7.7$. From these values intracellular $\mathrm{pH}$, derived from the Nernst equation, should have been $\sim 7.4$, i.e., considerably more alkaline than expected under physiological conditions. In addition, the time course of $E_{\mathrm{m}}$ during rewarming of Li-loaded specimens in the presence of 5-(N,N-dimethyl)amiloride was similar to the time course recorded when specimens cooled in low-Na, TEA-substituted Tyrode's solution were rewarmed in 5-( $N, N$-dimethyl)amiloride-free $\mathrm{Na}$-Tyrode's solution (compare Fig. 3 with Fig. 8). This indicates that an intracellular $\mathrm{Li}$ load is required for a $\mathrm{Na}, \mathrm{K}$-pump-induced hyperpolarization to develop via a 5-(N,N-dimethyl)amiloride-sensitive mechanism.

In principle, intracellular $\mathrm{Li}^{+}$could cause a Na-load to develop by stimulating exchange of intracellular protons for extracellular $\mathrm{Na}^{+}$. Various agents can stimulate the $\mathrm{Na}-\mathrm{H}$ exchanger by shifting the "set-point" for an intracellular "modifier" site in an alkaline direction (see reference 29 for review). However, when the loss of intracellular protons and $\mathrm{Na}^{+}$ which must have occurred during cooling in Li-Tyrode's solution, and the relatively large buffer capacity of cells is considered, an unreasonably large shift in the "set-point" would seem to be required for such a mechanism to induce the $\mathrm{Na}$ load. In addition, experimental evidence suggests that $\mathrm{Li}^{+} \mathrm{ac}-$ tually inhibits rather than stimulates the exchange of intracellular protons for extracellular $\mathrm{Na}^{+}(30,31)$. Therefore, it appears that a mechanism involving an actual exchange of intracellular $\mathrm{Li}^{+}$for extracellular $\mathrm{Na}^{+}$and the subsequent electrogenic Na-pumping of the consequent $\mathrm{Na}$ load offers the most likely explanation for the hyperpolarization occurring when Li-loaded tissue is transferred to Na-Tyrode's solution.

The rate of the $\mathrm{Na}-\mathrm{Li}$ exchange cannot be determined from the present study. However, it can be concluded from the experiment depicted in Fig. 9 that the exchange rate is not necessarily the rate limiting determinant for the prolonged pump-induced hyperpolarization. This conclusion is consistent with findings from experiments on guinea pig atria. The decrease in the intracellular $\mathrm{Li}^{+}$concentration $15 \mathrm{~min}$ after transfer from Li-Tyrode's solution in this study was severalfold larger than the $\mathrm{Na}, \mathrm{K}$-pump-mediated decrease reported for the intracellular $\mathrm{Na}^{+}$concentration in $\mathrm{Na}$-loaded guinea pig atria after $15 \mathrm{~min}$ under conditions expected to induce nearly maximal pump stimulation (see Fig. 1, reference 10).

It is interesting that the intracellular $\mathrm{Li}^{+}$concentration of guinea pig atria in this study 15 min after transfer to Na-Tyrode's solution ( $\sim 27 \mathrm{mmol} / \mathrm{liter}$ intracellular water) was lower than the $\mathrm{Li}^{+}$concentration $30 \mathrm{~min}$ after transfer of cat papillary muscles in similar experiments $(\sim 66 \mathrm{mmol} / \mathrm{liter}$ in- 
tracellular water) (3). This might be taken to indicate that $\mathrm{Na}-\mathrm{Li}$ counter transport occurs faster in guinea pig than in cat heart. Alternatively, the differences could be due to differences between delays in extracellular diffusion of $\mathrm{Li}^{+}$, a delay that for cat papillary muscle may be quite substantial during the first 30 min after the transfer (3). However, it does not seem plausible that delays in extracellular diffusion also accounts for 25

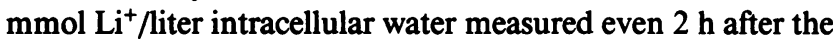
transfer of cat papillary muscles (3). Such findings suggests that not all intracellular $\mathrm{Li}^{+}$is freely exchangeable. The possibility that a fraction of intracellular $\mathrm{Li}^{+}$is not freely exchangeable, in combination with quantitative uncertainties regarding transmembrane ionic gradients (arising from delays in extracellular ionic equilibration), makes an accurate kinetic analysis of $\mathrm{Na}-\mathrm{Li}$ counter-transport difficult to perform in intact cardiac tissue. Such an analysis might require use of sarcolemmal membrane vesicles to ensure well-defined transmembrane ionic gradients.

Inhibition of the hyperpolarization in Li-loaded specimens by 5 -( $N, N$-dimethyl)amiloride (Fig. 8$)$ also suggests that the mechanism for the hyperpolarization recorded in the absence of drug (Fig. 2) involves an exchange of intracellular $\mathrm{Li}^{+}$for extracellular $\mathrm{Na}^{+}$. This is consistent with a recent report of inhibition of $\mathrm{Na}-\mathrm{Li}$ exchange in canine smooth muscle sarcolemmal membrane vesicles (28) by another derivative of amiloride, ethylisopropylamiloride. However, considerably higher concentrations $(0.1-1.0 \mathrm{mM})$ than used for the present study were needed to effectively inhibit the exchange, despite ethylisopropylamiloride being an order of magnitude more potent than 5-(N,N-dimethyl)amiloride (32). This could be due to species or tissue-dependent differences in drug-sensitivity or to differences in the experimental designs of the studies.

Both 5-( $N, N$-dimethyl)amiloride and ethylisopropylamiloride are potent inhibitors of the $\mathrm{Na}-\mathrm{H}$ exchanger. Inhibition of $\mathrm{Na}-\mathrm{Li}$ exchange might therefore be due to inhibition of the mechanism which usually mediates $\mathrm{Na}-\mathrm{H}$ exchange. However, amiloride and its derivatives also can block $\mathrm{Na}$, K-pumping (33), Na-Ca exchange (34) and ion permeation of $\mathrm{Na}$ and $\mathrm{K}$ channels $(35,36)$, at least in high concentrations. This suggests that inhibition of $\mathrm{Na}-\mathrm{Li}$ exchange could have been due to effects on any of these transport systems. The $\mathrm{Na}-\mathrm{Ca}$ exchanger does not have affinity for $\mathrm{Li}^{+}(27)$, however. Therefore it is unlikely that $\mathrm{Na}-\mathrm{Li}$ exchange could be mediated by an operational mode of the $\mathrm{Na}-\mathrm{Ca}$ exchanger. In the concentrations used in this study, 5-(N,N-dimethyl)amiloride was found to have essentially no effect on electrogenic $\mathrm{Na}$ pumping, indicating that, although the $\mathrm{Na}, \mathrm{K}$-pump dealt with the resulting $\mathrm{Na}$ load, it did not mediate the $\mathrm{Na}-\mathrm{Li}$ exchange. Finally, blockade of $\mathrm{Na}$ and $\mathrm{K}$ channels with TTX and $\mathrm{Ba}^{2+}$ did not inhibit hyperpolarization in Li-loaded specimens (Fig. 4), indicating that exchange of $\mathrm{Li}^{+}$for $\mathrm{Na}^{+}$involved neither $\mathrm{Na}$ nor $\mathrm{K}$ channels in the mechanism for the hyperpolarization. Although it cannot be excluded entirely that another currently unknown transport system, sensitive to 5-( $N, N$-dimethyl)amiloride, is able to transport $\mathrm{Li}^{+}$, it would seem that the effect of this drug on the counter transport system that usually mediates $\mathrm{Na}-\mathrm{H}$ exchange offers the most reasonable explanation for inhibition of $\mathrm{Na}-\mathrm{Li}$ exchange. This, in turn, suggests that $\mathrm{Na}-\mathrm{H}$ exchange and $\mathrm{Na}-\mathrm{Li}$ exchange are mediated by the same transport system. As first pointed out by Aronson (1), such common identity could have important implications for under- standing the association between abnormalities in $\mathrm{Na}-\mathrm{Li}$ counter transport and essential hypertension.

\section{Acknowledgments}

The authors thank Drs. Lawrence L. Michaelis, John H. Sanders, Jr., Renee S. Hartz, and James W. Frederiksen for providing atrial specimens and Amy L. Cigan and Taryn Markee for their skillful technical assistance.

Supported in part by grants in aid from The Reingold Estate, The Brinton Trust, The Chicago Heart Association, U. S. Public Health Service grants HL-27026 and RR-05370. Dr. Rasmussen is a recipient of a travel grant from the National Heart Foundation of Australia.

\section{References}

1. Aronson, P. S. 1983. Red-cell sodium-lithium counter-transport and essential hypertension. N. Engl. J. Med. 307:317.

2. Mahnensmith, R. L., and P. S. Aronson. 1985. The plasma membrane sodium-hydrogen exchanger and its role in physiological and pathophysiological processes. Circ. Res. 57:773-788.

3. Carmeliet, E. E. 1964. Influence of lithium ions on the transmembrane potential and cation content of cardiac cells. J. Gen. Physiol. 47:501-530.

4. Duhm, J. 1982. Lithium transport pathways in erythrocytes. In Basic mechanisms in the action of lithium. H. M. Emrich, J. B. Aldenhoff, and H. D. Lux, editors. Excerpta Medica, Amsterdam. 1-20.

5. Duhm, J., and B. F. Becker. 1979. Studies on lithium transport across the red cell membrane. J. Membr. Biol. 51:263-286.

6. Pandey, G. N., B. Sarkadi, M. Haas, R. B. Gunn, J. M. Davis, and D. C. Tosteson. 1978. Lithium transport pathways in human red blood cells. J. Gen. Physiol. 72:233-247.

7. Kahn, A. M. 1987. Difference between human red blood cell $\mathrm{Na}^{+}-\mathrm{Li}^{+}$counter-transport and renal $\mathrm{Na}^{+}-\mathrm{H}^{+}$exchange. Hypertension. 9:7-12.

8. Chipperfield, A. R. 1986. The $\left(\mathrm{Na}^{+}-\mathrm{K}^{+}-\mathrm{Cl}^{-}\right)$co-transport system. Clin. Sci. 71:465-476.

9. Haas, M., J. Schooler, and D. C. Tosteson. 1975. Coupling of lithium to sodium transport in human red cells. Nature (Lond.). 258:425-427.

10. Glitsch, H. G. 1972. Activation of the electrogenic sodium pump in guinea-pig auricles by internal sodium ions. J. Physiol. (Lond.). 220:565-582.

11. DiFrancesco, D. 1981. A new interpretation of the pace-maker current in calf Purkinje fibres. J. Physiol. (Lond.). 314:359-376.

12. Rasmussen, H. H., D. H. Singer, and R. E. TenEick. 1986. Characterization of a sodium pump-induced hyperpolarization in isolated human atrium. Am. J. Physiol. 251:H331-H339.

13. Snedecor, G. W., and W. G. Cochran. 1980. Statistical Methods. The lowa State University Press, Ames, IA. 215-237.

14. Ten Eick, R., H. Nawrath, T. F. McDonald, and W. Trautwein. 1976. On the mechanism of the negative inotropic effect of acetylcholine. Pfluegers Arch. Eur. Biol. 361:207-213.

15. Carmeliet, E., and K. Mubagwa. 1986. Characterization of the acetylcholine-induced potassium current in rabbit cardiac Purkinje fibres. J. Physiol. (Lond.). 371:219-237.

16. Piwnica-Worms, D., R. Jacob, N. Shigeto, C. R. Horres and M. Lieberman. 1986. $\mathrm{Na} / \mathrm{H}$ exchange in cultured chick heart cells: Secondary stimulation of electrogenic transport during recovery from intracellular acidosis. J. Mol. Cell. Cardiol. 18:1109-1116.

17. Wiggins, J. R., and P. F. Cranefield. 1974. Effect on membrane potential and electrical activity of adding sodium to sodium-depleted cardiac Purkinje fibers. J. Gen. Physiol. 64:473-483.

18. Edwards, C. 1982. The selectivity of ion channels in nerve and muscle. Neuroscience. 7:1335-1366. 
19. Narahashi, T., J. W. Moore, and W. R. Scott. 1964. Tetrodotoxin blockage of sodium conductance increase in lobster giant axons. J. Gen. Physiol. 47:965-974.

20. Sarkadi, B., J. K. Alifimoff, R. B. Gunn, and D. C. Tosteson. 1978. Kinetics and stoichiometry of Na-dependent $\mathrm{Li}$ transport in human red blood cells. J. Gen. Physiol. 72:249-265.

21. Eisner, D. A., W. J. Lederer, and R. D. Vaughan-Jones. 1981. The effects of rubidium ions and membrane potential on the intracellular sodium activity of sheep Purkinje fibres. J. Physiol. (Lond.). 317:189-205.

22. Gadsby, D. C., J. Kimura, and A. Noma. 1985. Voltage dependence of $\mathrm{Na} / \mathrm{K}$ pump current in isolated heart cells. Nature (Lond.). 315:63-65.

23. Ehrlich, B. E., and J. M. Diamond. 1980. Lithium, membranes, and manic-depressive illness. J. Membr. Biol. 52:187-200.

24. Grafe, P., J. Rimpel, M. M. Reddy, and G. ten Bruggengate. 1982. Lithium distribution across the membrane of motoneurons in the isolated frog spinal cord. Pfluegers Arch. Eur. Biol. 393:297-301.

25. Dunham, P. B., and O. Senyk. 1977. Lithium efflux through the $\mathrm{Na} / \mathrm{K}$ pump in human erythrocytes. Proc. Nat. Acad. Sci. USA. 74:3099-3103.

26. Eisner, D. A., and W. J. Lederer. 1985. Na-Ca exchange: Stoichiometry and electrogenicity. Am. J. Physiol. 248(Cell Physiol. 17):C189-C202.

27. Reuter, H., and N. Seitz. 1968. The dependence of calcium efflux from cardiac muscle on temperature and external ion composition. J. Physiol. (Lond.). 195:451-470.
28. Kahn, A. M., J. C. Allen, E. J. Cragoe Jr., R. Zimmer, and H. Shelat. 1988. Sodium-lithium exchange in sarcolemmal vesicles from canine superior mesenteric artery. Circ. Res. 62:478-485.

29. Grinstein, S., and A. Rothstein. 1986. Mechanisms of regulation of the $\mathrm{Na}^{+} / \mathrm{H}^{+}$exchanger. J. Membr. Biol. 90:1-12.

30. Kinsella, J. L., and P. S. Aronson. 1981. Interaction of $\mathrm{NH}_{4}^{+}$ and $\mathrm{Li}^{+}$with renal microvillus membrane $\mathrm{Na}^{+}-\mathrm{H}^{+}$exchanger. $A m . J$. Physiol. 241(Cell. Physiol. 10):C:220-226.

31. Ives, H. E., V. J. Yee, and D. G. Warnock. 1983. Mixed type inhibition of the renal $\mathrm{Na}^{+}-\mathrm{H}^{+}$antiporter by $\mathrm{Li}^{+}$and amiloride. Evidence for a modifier site. J. Biol. Chem. 258:9710-9716.

32. Vigne, P., C. Frelin, E. J. Cragoe, Jr., and M. Lazdunski. 1984. Structure-activity relationships of amiloride and certain of its analogues in relation to the blockade of the $\mathrm{Na}^{+}-\mathrm{H}^{+}$exchange system. $\mathrm{Mol}$. Pharmacol. 25:131-136.

33. Soltoff, S. P., and W. J. Mandel. 1983. Amiloride directly inhibits $\mathrm{Na}, \mathrm{K}-\mathrm{ATPase}$ activity of rabbit kidney proximal tubules. Science (Wash. DC). 220:957-958.

34. Schellenberg, G. D., L. Anderson, E. J. Cragoe, Jr., and P. D. Swanson. 1985. Inhibition of synaptosomal $\mathrm{Na}^{+}-\mathrm{Ca}^{2+}$ exchange transport by amiloride and amiloride analogues. Mol. Pharmacol. 27:537543.

35. Sariban-Sohraby, S., and D. J. Benos. 1986. The amiloride sensitive sodium channel. Am. J. Physiol. 250(Cell. Physiol. 19):C175-C190.

36. Harvey, R. D., and R. E. Ten Eick. 1989. On the role of sodium ions in the regulation of the inward rectifying potassium conductance in cat ventricular myocytes. J. Gen. Physiol. In press. 